\title{
Sistem Pakar Identifikasi Hama Pada Tanaman Cabai Dalam Upaya Meningkatkan Kualitas Cabai
}

\author{
Cep Lukman Rohmat \\ STMIK IKMI Cirebon \\ ceplukmanrohmat@gmail.com \\ Nana Suarna \\ STMIK IKMI Cirebon \\ St_nana@yahoo.com \\ Nining Rahaningsih \\ STMIK IKMI Cirebon \\ niningr157@yahoo.co.id \\ Elisa Sriyulia \\ STMIK IKMI Cirebon \\ elisa123@gmail.com
}

\begin{abstract}
The lack of supply of chili in the market causes the price to rise sharply. The price of chillies is almost unreasonable to far beyond the price of meat. Gray (Spodoptera litura) and Fungus colletotrichum are two of the main causes of chili plants which cause many chili plants to die or fail to harvest. must experience failure due to a lack of understanding of the beginning of the pest attacking the plants. In addition, the attack on chili plants is a high risk that must be faced by farmers.In this study using the Forward Chaining Method. Forward Chaining is an inference process that starts the search from the premise or input data in the form of symptoms leading to conclusions, namely the conclusion of pests that attack chilli plants and provide solutions for advice on handling and prevention based on observed symptoms. Data used from pest data caused by small animals such as caterpillars and flies.The results are expected to be able to identify quickly, precisely and accurately the chili plants. In addition, it is expected to be able to help farmers in anticipating the symptoms of the occurrence of pests in chili plants from an early age so that preventive measures will be taken immediately. Accuracy and accuracy are needed in identifying the symptoms of pest in accordance with the expected results.
\end{abstract}

Keywords: Expert System, Pests, Chili Plants, Forward Chaining.

\begin{abstract}
ABSTRAK
Minimnya pasokan cabai di pasaran menyebabkan harganya melonjak tajam. Penyebab utama nya adalah Ulat Grayak (Spodoptera litura) dan Cendawan colletotrichum yang mengakibatkan tanaman cabai banyak yang mati atau gagal panen. Para petani merasa cemas hasil panennya tidak memuaskan bahkan sampai harus mengalami gagal panen dikarenakan kurangnya pemahaman tentang awal mulanya hama tersebut menyerang tanamannya.Selain itu hama yang menyerang pada tanaman cabai merupakan resiko tinggi yang harus dihadapi oleh para petani. Penelitian ini menggunakan Metode Forward Chaining, yaitu merupakan proses inferensi yang dimulai pencarian dari premis atau data inputan berupa gejala menuju pada konklusi kesimpulan hama yang menyerang tanaman cabai juga memberikan solusi mengenai dalam hal saran penanganan dan pencegahan berdasarkan gejala-gejala yang diamati. Data yang digunakan dari data hama yang disebabkan oleh
\end{abstract}


binatang - binatang kecil seperti ulat dan lalat. Hasil dari penelitian ini dapat melakukan identifikasi sangat cepat, tepat dan akurat terhadap tanaman cabai. Selain itu diharapkan mampu membantu petani dalam mengantisipasi gejala terjadinya hama pada tanaman cabai sejak dini sehingga langkah pencegahan segera di lakukan. Dibutuhkan keakuratan dan ketepatan dalam mengidentifikasi gejala hama agar sesuai dengan hasil yang diharapkan.

Kata Kunci: Sistem Pakar, Hama, Tanaman Cabai, Forward Chaining.

\section{PENDAHULUAN}

\subsection{Latar Belakang Masalah}

Aneka jenis cabai yang dijual di pasar tradisional dapat digolongkan dalam dua kelompok, yakni cabai kecil (Capsicum frustescens) dan cabai besar (Capsicumannuum).Cabai kecil disebut cabai rawit, sedangkan yang besar disebut cabai merah. Namun, sering kali jumlah produksi cabai tidak mampu mencukupi kebutuhan permintaan pasar, sehingga menyebabkan tingginya harga cabai di pasaran. Salah satu penyebab rendahnya panen cabai adalah penggunaan benih unggul cabai yang sangat rendah sehingga menyebabkan tanaman cabai mudah terserang hama penyakit dan produktivitasnya yang tidak optimal.

Menurut Rahayu Sunarya, dkk, dalam penelitiannya yang berjudul Pengembangan Sistem Pakar Diagnosis Hama dan Penyakit pada Tanaman Bawang Merah Berbasis Android mengatakan bahwa :"Hama adalah perusak tanaman pada akar, batang, daun atau bagian tanaman lainya sehingga tanaman sehingga tanaman tidak dapat tumbuh dengan sempurna atau mati.

Berdasarkan penelitian terdahulu yang telah dilakukan oleh beberapa peneliti sebelumnya, yang difokuskan pada masalah yang akan diteliti yaitu mengidentifikasi hama pada tanaman cabai.Penelitian yang dilakukan olehResi Resmiati dan Asep Deddy Supriatna, Tahun 2016, yang berjudul Pengembangan Sistem Pakar Diagnosis Penyakit Tanaman Cabai Paprika Berbasis Androiddengan memfokuskan permasalahan pada sebuah program aplikasi berbasis web yang dapat membantu mengidentifikasi hama pada tanaman cabai.Sistem Pakar adalah program yang menggabungkan basis pengetahuan (Knowledge Base) yang berisi knowledge dengan sistem inferensi dan merupakan dari kecerdasan buatan. Sistem pakar ditujukan Sebagai penyedia nasihat dan sarana bantu dalam memecahkan masalah di bidang spesialisasi tertentu. Program ini akan menjadi sebagai konsultan yang cerdas atau penasehat dalam suatu lingkungan keahlian tertentu.

Permasalahannya adalah banyak para petani kurang memahami gejala - gejala hama yang menyerang tanaman cabai sehingga banyak para petani hasil panennya kurang memuaskan bahkan ada beberapa petani yang gagal panen. Selain itu para petani kurang memperhatikan cara menanam tanaman cabai yang baik dan benar.

Penyebab masalah dalam penelitian ini adalahkurangnya pengetahuan para petani dalam bercocok tanamdalam menangani hama pada tanaman cabai.Sehingga menyebabkan banyak para petani yang gagal panen, sepertigangguan hama Thrips, Kutu Kebul, Kutu Daun, Tungau, Ulat Grayak dan Lalat Buah.Selain itu faktor lain yang menyebabkan gagal panen adalah faktor cuaca yang tidak menentu serta kekurangan air sehingga hama begitu sangat rentan terhadap tanaman cabai.

Berdasarkan uraian tersebut maka di diusulkan penelitian dengan judul "sistem pakar identifikasi hama pada tanaman cabai dalam upaya meningkatkan kualitas cabai”

Adapun yang menjadi alasan dilakukannya penelitian tersebut adalah untuk mengetahui dunia pertanian terutama terhadap tanaman cabai, serta untuk mengetahui hama apa saja yang menyerang tanaman cabai dan bagaimana cara penanganannya degan cepat dan tepat untuk mengatasi hama tersebut. 


\subsection{Tinjauan Pustaka}

\subsubsection{Penelitian Terdahulu}

Berdasarkan Penelitian Zayin Sukri dkk dalam penelitian yang berjudul Sistem Pakar Diagnosis Hama dan Penyakit Tanaman Jeruk Menggunakan Metode Euclidean Distance, menyatakan bahwa :"Hama adalah makhluk hidup yang mengurangi ketersediaan, kualitas atau jumlah beberapa sumber daya manusia.Sumber daya manusia itu sendiri bisa disebut berupa tumbuhan atau binatang yang dipelihara oleh manusia, untuk kehidupan manusia. Sedangkan kegemaran manusia yang dimiliki misal binatang peliharaan, tanaman hias, tanaman kebun atau di tempat lainnya. Sumber daya yang mungkin dipergunakan untuk kesehatan, kenyamanan dan ketenangan yang dari waktu ke waktu dapat terancam oleh tanaman yang menyebabkan elergi, makhluk hidup penyebar penyakit, gigitan serangga atau binatang pengganggu lainnya. Mahluk hidup yang menjadi hama tak terbatas pada kelas atau phylum tertentu. Serangga yaitu ras binatang yang sering menjadi hama adalah tungau, kutu, nematoda, moluska, dan spesies invertebrata lainnya yang yang diketahui sebagai hama.

\subsubsection{Sistem Pakar}

Sistem pakar merupakan sistem yang berbasis pengetahuan yang menyediakan solusi dengan mengadopsi kemampuan pakar untuk menyelesaikan masalah dalam suatu domain pengetahuan yang spesifik. Umumnya pengetahuan pada sistem pakar diambil dari seorang atau tim yang merupakan pakar pada bidang tertentu. Dengan sistem pakar ini, orang awam pun dapat dibantu dalam menyelesaikan masalahnya atau hanya sekedar mencari informasi berkualitas yang sebenarnya hanya dapat diperoleh dari para pakar di bidangnya.

\subsubsection{Forward Chaining}

Menurut Tika (2011) metode forward chaining merupakan teknik pencarian yang dimulai dengan fakta yang diketahui, kemudian mencocokkan fakta-fakta tersebut dengan bagian IF dari rules IF-THEN. Bila ada fakta yang cocok dengan bagian IF, maka rule tersebut dieksekusi. Bila sebuah rule dieksekusi, maka sebuah fakta baru pencocokan berhenti bila tidak ada lagi rule yang bisa dieksekusi.

Metode inferensi forward chaining sebenarnya salah satu metode yang digunakan didalam sistem pakar.Metode inferensi forward chainingyang dapat melakukan diagnosa penyakit berdasarkan gejala - gejala penyakit yang dimasukkan dan memberikan informasi penyakit tersebut beserta cara pengobatannya.

Berdasarkan Penelitian Endang Restu Patmawati dalam penelitiannya yang berjudul Sistem Pakar Diagnosa Penyakit Kucing Menggunakan Metode Forward Chaining, menyatakan bahwa :"Dengan metode forward chainingini cukup bisa membantu dalam memberikan informasi kepada masyarakat luas pada umumnya dan para pecinta kucing pada khususnya untuk mengetahui gejala-gejala yang diderita kucing. Untuk memberikan informasi mengenai kemungkinan penyakit yang diderita pada kucing dan penanggulangan yang disarankan menggunakan sistem yang telah terkomputerisasi."

\subsubsection{Peningkatan Produksi Cabai}

Berdasarkan Penelitian Ade Eka Novita Pratiwi dalam penelitian yang berjudul Sistem Diagnosa Penyakit Pada Tanaman Cabai Merah Dengan Metode Backward Chaining (Studi Kasus: Petani Cabai Merah Desa Grobongan Kabupaten Madiun), menyatakan bahwa:"Tanaman cabai merah menyerupai salah satu pohon hortikultura yang mempunyai banyak jenis penyakit dan sangat mudah menulari pada tanaman lain jika tidak cepat diketahui gejalanya. Dalam mendiagnosis penyakit tanaman cabai, petani masih menggunakan cara yang sederhana dengan menganalisa gejala-gejala pada tanaman cabai 
sehingga membutuhkan waktu untuk mengenali jenis penyakit cabai. Penelitian sistem pakar diagnosa penyakit tanaman cabai merah ini bertujuan untuk merancang dan membangun suatu sistem untuk mediagnosa penyakit tanaman cabai merah". [5]

\section{METODOLOGI}

Penelitian ini merupakan penelitian kuantitatif yang akan mencoba mengimplementasikan metode Forward Chaining pada sistem pakar untuk melakukan identifikasi hama pada tanaman cabai, dengan tujuan membantu para petanidalam menganalisa dan mengidentifikasi serta memberikan solusi terhadap tanaman cabai yang terserang hama, dan dapat digunakan sebagai alat deteksi dini dalam mengidentifikasi hama pada tanaman cabai.

Pada gambar dapat dijelaskan Observasi adalah kegiatan yang dilakukan para pakar tanaman cabai lakukan untuk bisa melihat suatu gejala fisik pada tanaman cabai. Observasi akan dilakukan secara terus menurus sampai pada tahap penarikan kesimpulan dari semua fakta yang didapatkan dari pakar.

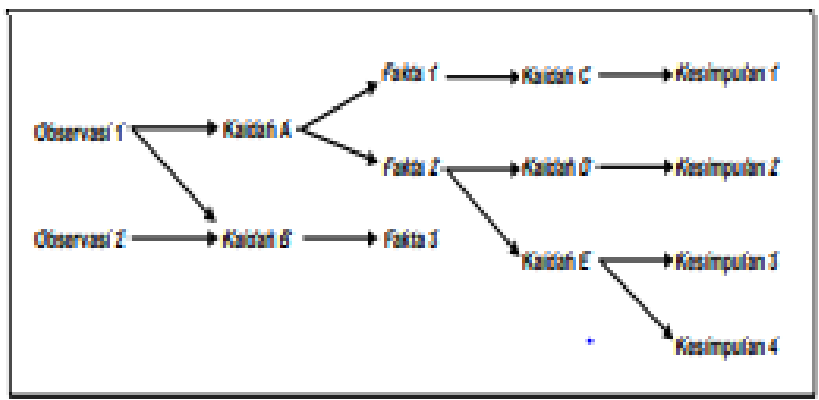

Gambar 1. Forward chaining

\subsection{Teknik Pengumpulan dan Analisis Data}

Tahapan ini menjelaskan tentang teknik pengumpulan dan analisis data penelitian yang berjudul Identifikasi Hama Pada Tanaman Cabai Melalui Penerapan Sistem Pakar Dalam Upaya Meningkatkan Kualitas Cabai, didalamnya terdapat beberapa teknik pengumpulan data dan Teknik Analisa Data. Disertai juga penjelasan singkat bagaimana prosedur penelitian akan dilakukan

\subsubsection{Teknik Pengumpulan Data} berikut :

Didalam teknik pengumpulan data, terdapat 4 tahapan/penjelasan adalah sebagai

1. Observasi

Tahapan observasi dilakukan dengan pengambilan data dan pengamatan dilapangan, data penelitian pendukung penelitian merupakan hasil pengumpulan data jenis hama tanaman cabai, yang diperoleh dari petani.

2. Wawancara

Wawancara dilakukan dengan cara mewawancari Bapak Edi.

3. Studi Dokumentasi

Dalam penelitian menggunakan dokumen pendukung yaitu, dokumen internal, dimana dokumen tersebut, menjadi dasar penelitian yang dilakukan, dua penjelasan dokumen Internal.

4. Kuesioner (Angket)

Kuesioner adalah teknik pengumpulan data yang dilakukannya dengan memberi beberapa pertanyaan atau pernyataan tertulis kepada responden untuk dijawab. Kuesioner sebagai cara pengumpulan data yang efisien apabila peneliti mengetahui variabel yang akan diukur. 


\subsubsection{Teknik Analisis Data}

Didalam teknik Analisis data, terdapat 3 tahapan, penjelasan tahap teknik pengumpulan Analisis Data, sebagai berikut :

1. Pengumpulan Data

Pengumpulan data yang diperoleh dari hasil observasi, wawancara, studi dokumentasi dan instrument penelitian, yang telah dilakukan meliputi :

a. Diperoleh laporan hasil wawancara dari petani.

b. Diperoleh data observasi seperti laporan data dilapangan, laporan dari petani kemudian data akan diolah.

c. Diperoleh data studi dokumentasi seperti jurnal, paper, proceding dan data - data artikel serta dokumentasi hasil penyebarankuesioner.

d. Dihasilkan instrument untuk melaksanakan wawancara, observasi dan Studidokumentasi.

2. Reduksi Data

Berdasarkan data yang telah di dapat dari hasil observasi, wawancara, studi dokumentasi dan instrument penelitian, yang telah dilakukan, maka dilakukan reduksi data (pengolahan data), untuk mendukung penelitian yang akan dilakukan, yang hasilnya dapat memberikan gambaran apa yang harus dilakukan peneliti.

3. Teknik Penyajian Data

Didasarkan pada hasil pengolahan data (reduksi data), meghasilkan laporan analisa data berbentuk barchart dan kriteria yang akan dipergunakan sebagai data pendukung penelitian,

4. Populasi

Populasi adalah wilayah generalisasi yang terdiri atas obyek/ subyek yang mempunyai kualitas dan karakteristik tertentu yang ditetapkan oleh peneliti untuk dipelajari dan kemudian ditarik kesimpulannya.

5. Sampel

Sampel adalah bagian dari jumlah dan karakteristik yang dimiliki oleh populasi tersebut. bila populasi besar, dan peneliti tidak mungkin mempelajari semua yang ada pada populasi.

6. Uji Validitas

Validitas adalah ketepatan atau kecermatan suatu instrumen dalam mengukur apa yang ingin diukur. Dalam pengujian instrumen pengumpulan data, validitas bisa dibedakan menjadi validitas faktor dan validitas item.

\section{ANALISIS DAN PERANCANGAN}

\subsection{Perancangan (Data Flow Diagram)}

Data flow diagram adalah sebuah teknik grafis yang menggambarkan aliran informasi dan transformasi yang diaplikasikan pada saat data bergerak dari input menjadi output.

1. Diagram Konteks

Diagram konteks adalah sebuah diagram sederhana yang menggambarkan hubungan antara entitas luar, masukan dan keluaran dari sistem. entitas yang ada didalam sistem pakar diagnosa hama cabai. 


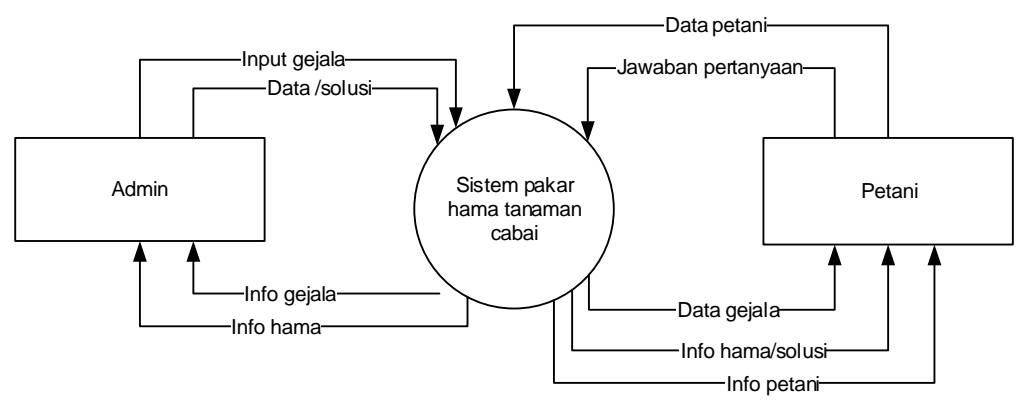

Gambar 2. Diagram konteks

2. Data Flow Diagram (DFD) Level 0

DFD level 0 membahas tentang penjabaran sistem yang akan dirancang berdasarkan rancangan pada konteks diagram. Adapun rancangannya seperti pada gambar berikut :

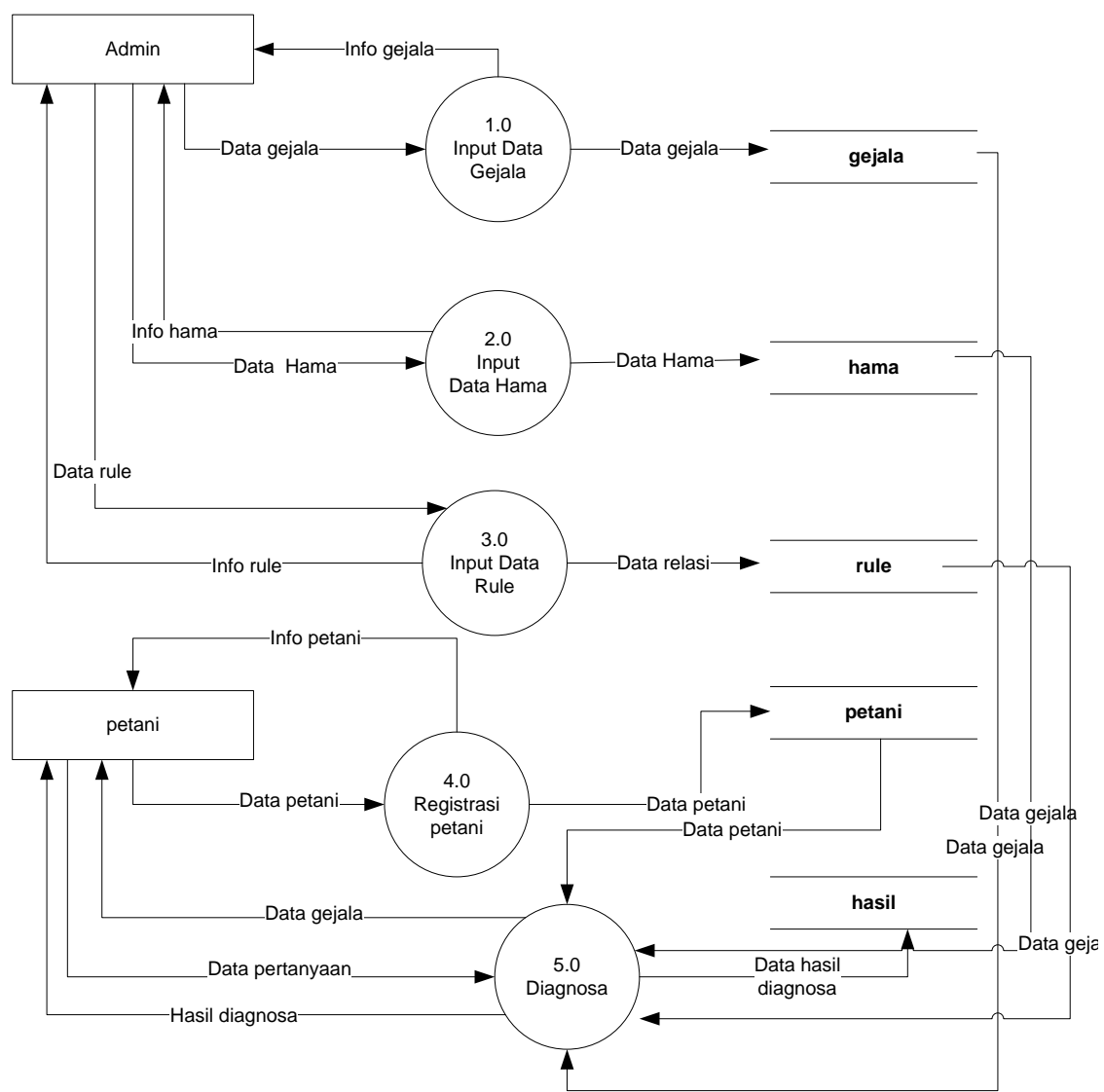

Gambar 3. Data Flow Diagram Level 0

\subsection{Perancangan Basis Data}

Rancangan database bertujuan untuk membangun basis data daripada sistem. Sub bagian dari pengerjaan basis data meliputi perancangan ERD, rancangan relasi tabel dan rancangan tabel.

\section{ERD}

ERD yaitu suatu model untuk menjelaskan relasi antar data pada database berdasarkan objek-objek dasar data yang mempunyai relasi antar tabel. ERD untuk memodelkan struktur data, untuk menggambarkannya dengan beberapa notasi dan simbol. Untuk lebih jelasnya adalah sebagai berikut : 


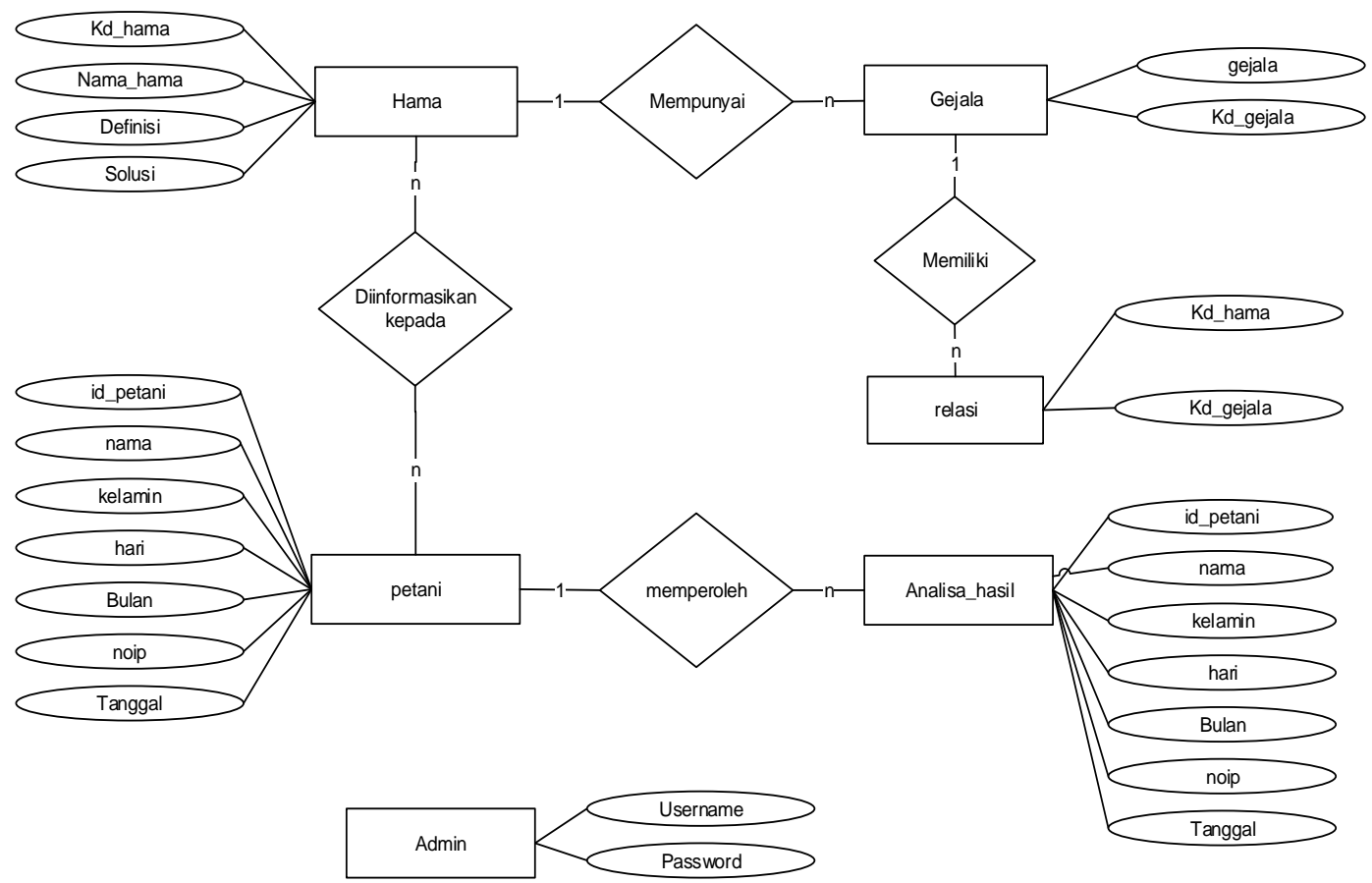

Gambar 4. ERD (Entity Relationship Diagram)

\subsection{Perancangan Antarmuka}

Adapun perancangan antarmuka sebagai berikut :

1. Desain Halaman Login Admin Pakar

Halaman login admin pakar yaitu untuk login bagi admin pakar sehingga akan memperoleh akses menggunakan sistem. Adapun rancangannya sebagai berikut:

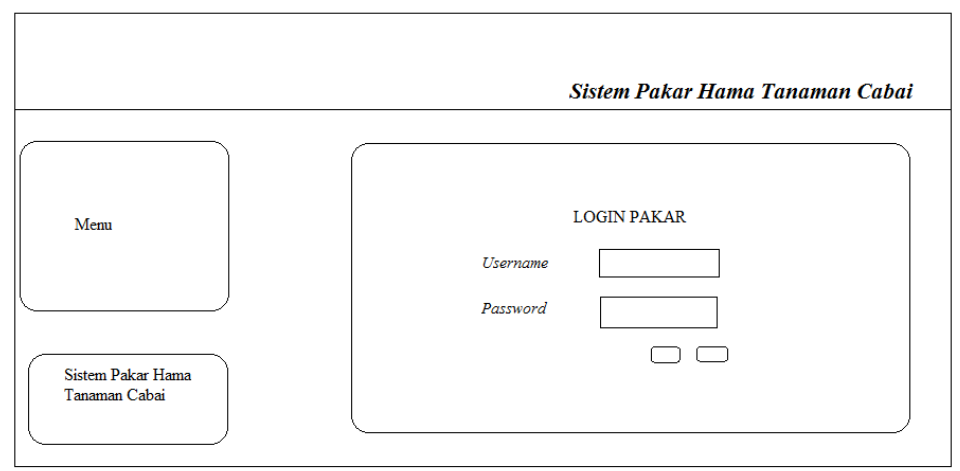

Gambar 5. Form Login Admin Pakar

2. Desain Halaman Form Registrasi Petani/user

Halaman registrasi Petani yaitu untuk melakukan registrasi bagi user untuk menggunakan aplikasi tersebut. Rancangannya sebagai berikut : 


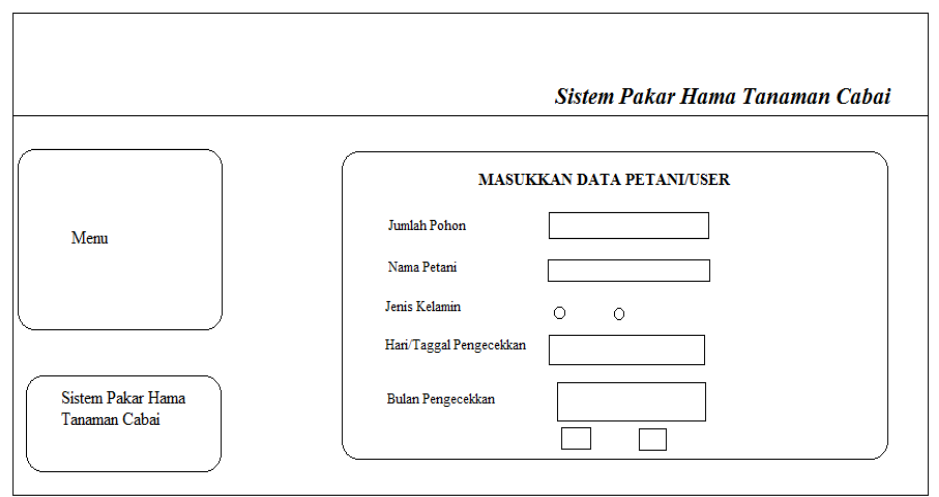

Gambar 6. Form Registrasi Petani

3. Desain Halaman Admin

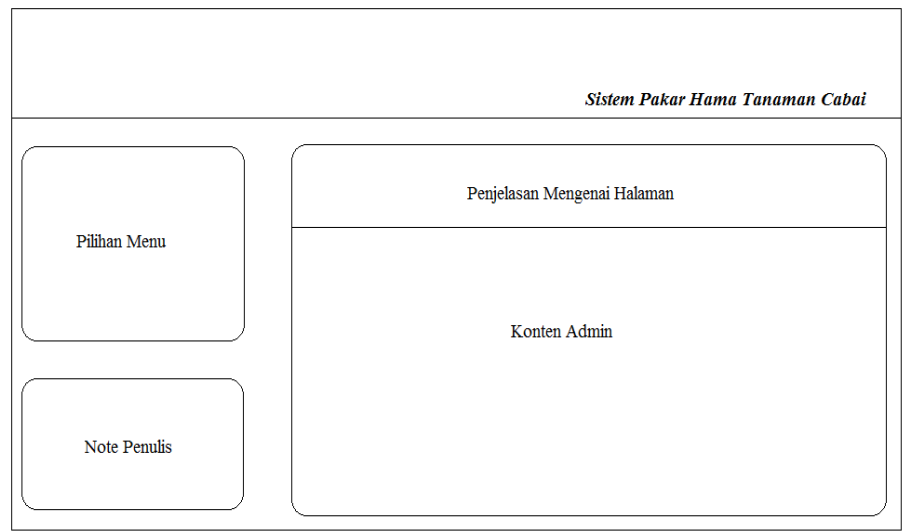

Gambar 7. Halaman Admin

4. Desain Halaman Menu Hama Admin

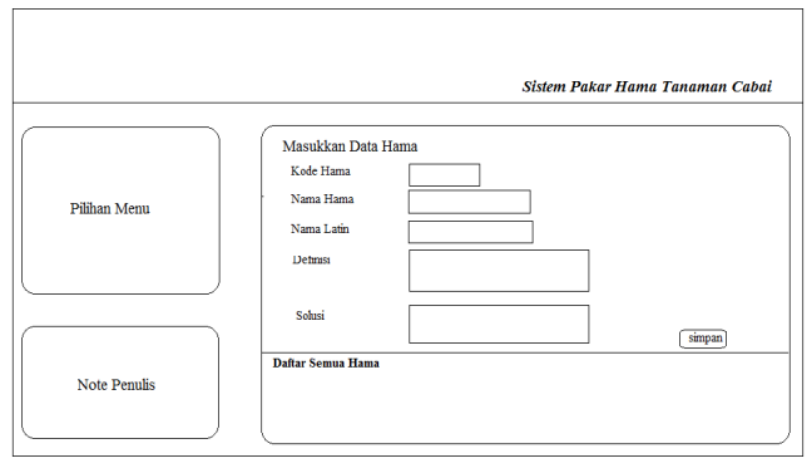

Gambar 8. Menu Hama Admin

5. Desain Halaman Menu Gejala Admin

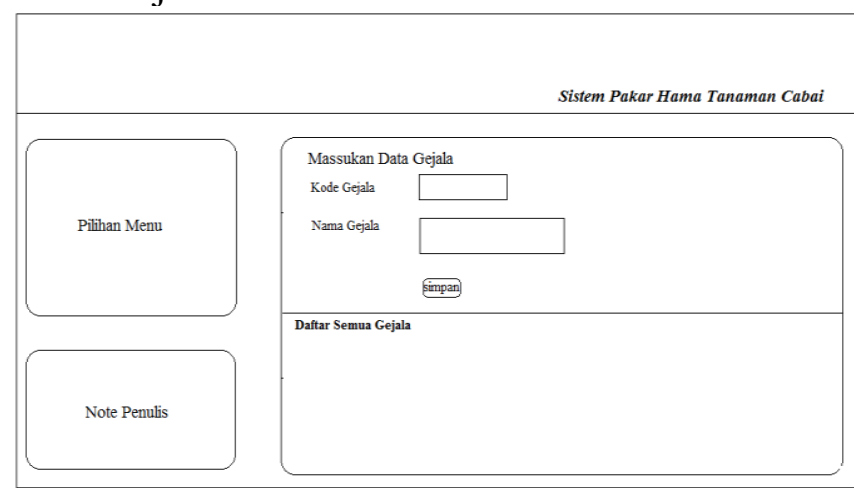


6. Desain Halaman Menu Relasi

Gambar 9. Menu Gejala Admin

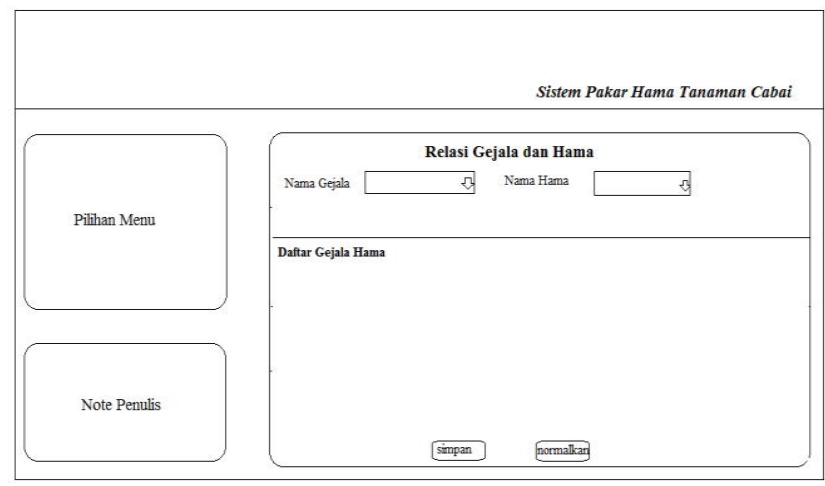

Gambar10. Menu Relasi

\subsection{Perancangan Pengambilan Keputusan}

Adapun perancangan pengambilan keputusan sebagai berikut :

1. Tabel hubungan Gejala dengan Hama tanaman

Tabel 1. Rule basis pengetahuan dengan Forward Chaining

\begin{tabular}{|l|l|l|l|l|l|l|}
\hline \multirow{2}{*}{$\begin{array}{c}\text { Kode } \\
\text { Gejala }\end{array}$} & \multicolumn{1}{|c|}{ Gejala } & \multicolumn{5}{c|}{ Kode Hama } \\
\hline & & H1 & H2 & H3 & H4 & H5 \\
\hline G001 & $\begin{array}{l}\text { Daun berubah warna menjadi } \\
\text { cokelat }\end{array}$ & $\sqrt{ }$ & & & $\sqrt{ }$ & \\
\hline G002 & $\begin{array}{l}\text { Daun dan tunas atau pucuk } \\
\text { menggulung ke atas }\end{array}$ & $\sqrt{ }$ & & & & \\
\hline G003 & Pucuk tanaman menjadi mati & & & & & \\
\hline G004 & Adanya bercak nekrotik pada daun & & $\sqrt{ }$ & & & \\
\hline G005 & Adanya embun muda pada daun & & & & & \\
\hline G006 & Adanya bercak di permukaan daun & & & $\sqrt{ }$ & & \\
\hline G007 & Daun menjadi keriting & $\sqrt{ }$ & & & $\sqrt{ }$ & \\
\hline G008 & Adanya kutu yang bergerombol & & & & & \\
\hline G009 & Daun mengeriput & & & $\sqrt{ }$ & & \\
\hline G010 & Daun terpuntir & & & $\sqrt{ }$ & & \\
\hline G011 & Tanaman cenderung kerdil & & & $\sqrt{ }$ & & \\
\hline G012 & Daun berwarna kekuningan & & & $\sqrt{ }$ & & \\
\hline G013 & Daun menggulung & & & $\sqrt{ }$ & $\sqrt{ }$ & \\
\hline G014 & Tanaman layu & & & $\sqrt{ }$ & & \\
\hline G015 & Tanaman Mati & & & $\sqrt{ }$ & & \\
\hline G016 & Daun menebal & & & & $\sqrt{ }$ & \\
\hline G017 & Daun menjadi kaku & & & $\sqrt{ }$ & \\
\hline G018 & Tunas dan bunga cabai gugur & & & & \\
\hline G019 & Adanya bercak-bercak putih yang \\
menerawang & Daun menjadi habis & & & & & \\
\hline G020 & & & & & & \\
\hline & & & & & & \\
\hline
\end{tabular}




\begin{tabular}{|l|l|l|l|l|l|l|} 
G021 & Buah cabai menjadi busuk & & & & & $\sqrt{ }$ \\
\hline G022 & $\begin{array}{l}\text { Adanya titik hitam pada bagian } \\
\text { pangkal buah }\end{array}$ & & & & & $\sqrt{ }$ \\
\hline G023 & Cabai menjadi rontok & & & & & $\sqrt{ }$ \\
\hline G024 & Muncul benjolan seperti tumor & & & & & \\
\hline
\end{tabular}

2. Analisa Rule Forward Chaining untuk mendiagnosa hama pada tanaman cabai.

a. Rule untuk penelusuran hama H001 (Hama Thirps)

IF Daun berubah warna menjadi cokelat (G001) AND Daun dan tunas atau pucuk menggulung ke atas (G002) AND Daun menjadi keriting (G007) AND Muncul benjolan seperti tumor (G024), THEN Hama Thirps (H001).

b. Rule untuk penelusuran hama H002 (Hama Kutu Kebul)

IF Adanya bercak nekrotik pada daun (G004) AND Adanya embun muda pada daun (G005) THEN Hama Kutu Kebul (H002).

c. Rule untuk penelusuran Hama H003 (Hama Kutu Daun)

IF Adanya bercak di permukaan daun (G006) AND Adanya kutu yang bergerombol (G008) AND Daun mengeriput (G009) AND Daun terpuntir (G010) AND Tanaman cenderung kerdil (G011) AND Daun berwarna kekuningan (G012) AND Daun menggulung (G013) AND Tanaman layu (G014) AND Tanaman Mati (G015) THEN Hama Kutu Daun (H003).

d. Rule untuk penelusuran hamaH004 (Hama Tungau)

IF Daun berubah warna menjadi cokelat (G001) AND Daun menjadi keriting (G007) AND Daun menggulung (G013) AND Daun menebal (G016) AND Daun menjadi kaku (G017) AND Tunas dan bunga cabai gugur (G016) THEN Hama Tungau (H004).

e. Rule untuk penelusuran hamaH005 (Hama Ulat Qrayafc)

IF Daun mengeriput (G009) AND Adanya bercak-bercak putih yang menerawang (G019) AND Daun menjadi habis (G020) THEN Hama Ulat Qrayaftc (H005).

3. Pohon Keputusan 


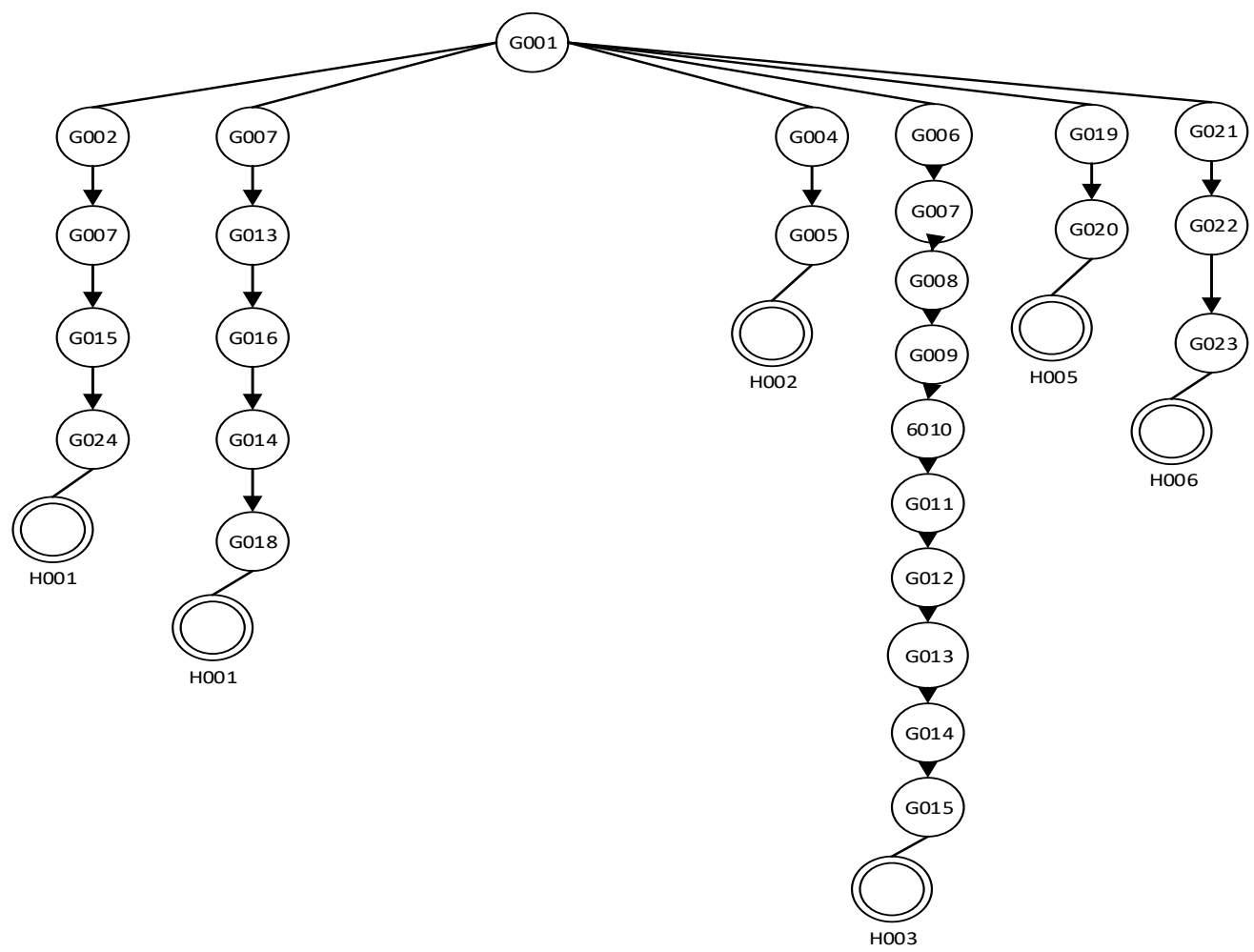

Gambar 11. Pohon Keputusan

\section{PENUTUP}

Berdasarkan permasalahan yang telah dibahas diatas maka dapat diambil beberapa kesimpulan, di antaranya :

1. Aplikasi Sistem Pakar yang dibangun dapat dijadikan sebagai alat bantu oleh petani ketika sedang mengidentifikasi hama pada tanaman cabai yang di keluhkan oleh petani sehingga dapat mempermudah dalam penelusuran atau pencarian gejala, serta pengendalian yang harus di lakukan.

2. Hasil hipotesis penelitian ini berdasarkan nilai t hitung $=2,806>2,063$ (Ho ditolak, Ha diterima). Identifikasi Hama Pada Tanaman Cabai Melalui Penerapan Sistem Pakar Dalam Upaya Meningkatkan Kualitas Cabai lebih dari 70\%. Dan berdasarkan nilai sig = $0,010<0,05$ (Ha diterima, Ho ditolak).

3. Dari hasil penelitian yang terkumpul diperoleh dari penyebaran kuesioner/angket kepada para petani yang ada di kecamatan Sukahaji Kabupaten Majalengka. Untuk menghitung data - data statistiknya terlebih dahulu penulis menguji validitas dan reliabilitasnya kemudian di olah dengan menggunakan SPSS. Hasil uji hipotesis menggunakan one sample test memperoleh t hitung sebesar 2,806 dengan nilai signifikansi 0,010 dan t tabel dari 24 adalah 2,063. Maka berdasarkan nilai t hitung $=2,806>2,063$ (Ho ditolak, Ha diterima).

\section{DAFTAR PUSTAKA}

E. H. Wijaya and N. Hidayat, "Diagnosis Penyakit Cabai Dengan Menggunakan Metode Forward Chaining - Dempster-Shafer," J. Pengemb. Teknol. Inf. dan Ilmu Komput., vol. 2, no. 12, pp. 7202-7208, 2018.

R. Resmiati and A. D. Supriatna, "Pengembangan Sistem Pakar Diagnosis Penyakit Cabai Paprika Berbasis Android," J. Algoritm., vol. 13, no. 1, pp. 191-197, 2016, doi: 10.33364/algoritma/v.13-1.191. 
T. Christy, "Implementasi sistem pakar diagnosa penyakit cabe menggunakan metode forward chaining," TMIK R., vol. 15, no. 1, pp. 353-358, 2018.

T. W. Y. R. W. U. Sri Hariyati Fitriasih, "Sistem Pakar Diagnosa Hama Dan Penyakit Tanaman Cabai Besar Menggunakan Metode Certainty Factor," J. Ilm. SINUS, vol. 15, no. 2, pp. 13-24, 2017, doi: 10.30646/sinus.v15i2.302.

A. Eka, N. Pratiwi, and K. Kunci, "Chaining ( Studi Kasus : Petani Cabai Merah Desa Grobongan Kabupaten Madiun ),” vol. 3, no. 1, pp. 1-10, 2018. 